\title{
Energy metabolism of Actinobacillus actinomycetemcomitans during anaerobic and microaerobic growth in low- and high- potassium continuous culture
}

\author{
Hiroyuki Ohta, ${ }^{1}$ Tetsuyoshi Inoue ${ }^{2}$ and Kazuhiro Fukui ${ }^{2}$
}

\begin{abstract}
Author for correspondence: Hiroyuki Ohta. Tel: +8129888 8684. Fax: + 81298888525. e-mail: hohta@acs.ibaraki.ac.jp
\end{abstract}

1 Department of Bioresource Science, Ibaraki University College of Agriculture, Ami-machi, Ibaraki 3000393, Japan

2 Department of Microbiology, Okayama University Dental School, Shikata-cho 2-chome, Okayama 700-8525, Japan
Actinobacillus actinomycetemcomitans, a member of the gamma subclass of the Proteobacteria, has been implicated as the agent responsible for human periodontitis. In this study, A. actinomycetemcomitans 301-b was grown in fructose-limited chemostat cultures under anaerobic [redox potential $\left(E_{\mathrm{h}}\right)$ $<-400 \mathrm{mV}]$ and microaerobic $\left(E_{\mathrm{h}}=-200 \mathrm{mV}\right)$ conditions to characterize its energy metabolism. Effects of $\mathrm{K}^{+}$and $\mathrm{Na}^{+}$on growth and metabolism were also examined. In a control medium containing $5.2 \mathrm{mM} \mathrm{K}^{+}$and $24 \mathrm{mM} \mathrm{Na}^{+}$, the molar growth yield on fructose $\left(Y_{\text {fructose }}\right)$ of microaerobic cultures was 1.3 times higher than the yield of anaerobic cultures at $D \leq 0 \cdot 10 \mathrm{~h}^{-1}$, but the difference in the $Y_{\text {fructose }}$ between microaerobic and anaerobic cultures decreased at $D>$ $0 \cdot 10 \mathrm{~h}^{-1}$. When the ATP yield from fermentation was estimated from the amounts of fructose consumed and acetate formed, the value of the microaerobic culture ( $2.49 \mathrm{~mol}$ ATP produced per mol fructose consumed) was lower than the anaerobic value [3.13 mol ATP (mol fructose) $\left.{ }^{-1}\right]$. Therefore, ATP production from fermentation could not account for the increase in the $Y_{\text {fructose }}$ at $D \leq 0.10 \mathrm{~h}^{-1}$ and thus additional ATP was expected to be generated via respiration. Assuming that the $Y_{\text {ATP }}$ (g cells formed per mol ATP synthesized) was similar between anaerobic and microaerobic cultures, the estimated ATP yield from respiration was between 1.2 and $2.0 \mathrm{~mol}$ ATP (mol fructose) $)^{-1}$ below $D=0.10 \mathrm{~h}^{-1}$ and decreased to $0.3 \mathrm{~mol}$ ATP (mol fructose) ${ }^{-1}$ when $D$ was increased to $0.19 \mathrm{~h}^{-1}$. Such growth-rate-dependent decreases in the $Y_{\text {fructose }}$ and the estimated ATP production from respiration were also observed in a high$\mathrm{Na}^{+}\left(5.2 \mathrm{mM} \mathrm{K}^{+}\right.$and $\left.106 \mathrm{mM} \mathrm{Na}^{+}\right)$culture but not in a high-K $\mathrm{K}^{+}\left(81 \mathrm{mM} \mathrm{K}^{+}\right.$and $24 \mathrm{mM} \mathrm{Na}{ }^{+}$) culture. In the high- $K^{+}$culture, the microaerobic $Y_{\text {fructose }}$ was 1.4-2.0 times higher than the anaerobic value and the respiration-derived ATP yield was estimated to be between 1.2 and 1.9 mol ATP (mol fructose) $)^{-1}$ over a wide range of dilution rate. These results suggest that higher concentrations of extracellular $\mathrm{K}^{+}$are required for the respiration to occur in rapidly growing cells of $\boldsymbol{A}$. actinomycetemcomitans.

Keywords: fructose metabolism, microaerophile, chemostat culture, potassium ion, periodontopathogen

\section{INTRODUCTION}

Actinobacillus actinomycetemcomitans, a member of the gamma subclass of the Proteobacteria, is associated with several severe forms of human periodontitis (Slots et al., 1980; Slots \& Schonfeld, 1991; Wilson \& Henderson, 1995; Zambon, 1985). This bacterium was found at higher proportions in moderate $(5-7 \mathrm{~mm}$ in depth) than in deeper periodontal pockets of patients (Dzink et al., 1985). Since moderate pockets exhibit relatively higher oxygen tensions than deeper pockets (Loesche et al., 1983), conditions favourable for the growth of A. actinomycetemcomitans probably include moderate levels of oxygen such as those encountered frequently in such moderate periodontal pockets. In our previous study, the microaerophilic growth of A. actino- 
mycetemcomitans 301-b was characterized in chemostat cultures equipped with a redox control system (Ohta et al., 1996b). When the bacterium was grown at a dilution rate of $0 \cdot 10 \mathrm{~h}^{-1}$, optimum growth was recorded in microaerobic cultures at culture redox potential $\left(E_{\mathrm{h}}\right)$ values of -300 to $-200 \mathrm{mV}$, and growth inhibition occurred under highly aerated conditions $\left(E_{\mathrm{h}}\right.$ $>-100 \mathrm{mV}$ ). The recorded growth yield of the microaerobic culture was only about 1.3 times the yield of anaerobic cultures $\left(E_{\mathrm{h}}<-400 \mathrm{mV}\right)$. One possible explanation for this small increase in the growth yield was an increase in substrate-level phosphorylation at the site of acetate kinase in the fructose fermentation (Ohta et al., 1996b). Alternatively, the occurrence of respiratory-chain phosphorylation was possible, since A. actinomycetemcomitans has a respiratory system with oxygen as the terminal electron acceptor (Mannheim et al., 1978).

In this study, we examined whether or not respiratorychain phosphorylation occurs in A. actinomycetemcomitans. To this end, several growth parameters, including the specific rate of ATP production from fructose catabolism, were estimated for steady-state cultures at different dilution rates. Our study also focused on the effect of potassium on the ATP production rate. Potassium is influential in bacterial energy metabolism (Hueting et al., 1979) and a predominant cation in oral environments such as the dental plaque and gingival fluid (Tatevossian \& Gould, 1976).

\section{METHODS}

Bacterial strain and medium. A. actinomycetemcomitans 301-b (Ohta et al., 1987, 1996b; Inouye et al., 1990) was used throughout this study. The growth medium (AA medium; Ohta et al., 1989) contained the following ingredients per 1: $\mathrm{Na}_{2} \mathrm{SO}_{4}, 0.5 \mathrm{~g} ; \mathrm{KH}_{2} \mathrm{PO}_{4}, 0.2 \mathrm{~g} ; \mathrm{MgSO}_{4} .7 \mathrm{H}_{2} \mathrm{O}, 0.5 \mathrm{~g}$; $\mathrm{NaCl}, 1.2 \mathrm{~g} ; \mathrm{NH}_{4} \mathrm{Cl}, 0.3 \mathrm{~g} ; \mathrm{KCl}, 0.3 \mathrm{~g} ; \mathrm{CaCl}_{2} .2 \mathrm{H}_{2} \mathrm{O}, 0.15 \mathrm{~g}$; Bacto yeast extract, $2.0 \mathrm{~g}$; resazurin, $0.001 \mathrm{~g}$; Tris, $6.05 \mathrm{~g}$. The trace element solution described before (Ohta \& Gottschal, 1988) was also added. Fructose was chosen as the growthlimiting nutrient because the growth rate of strain 301-b was higher with fructose than with any other sugars (Ohta et al., 1989, 1996a, b). Filter-sterilized solutions of fructose were added to the autoclaved medium aseptically at final concentrations of $6 \cdot 6-7 \cdot 5 \mathrm{mM}$. For the examination of effects of $\mathrm{K}^{+}$ on growth, $\mathrm{KCl}$ in AA medium was increased to $1 \cdot 5,3 \cdot 0,6 \cdot 0$ or $12 \cdot 0 \mathrm{~g} \mathrm{l}^{-1}$, while for the effect of $\mathrm{Na}^{+}, \mathrm{NaCl}$ in the medium was increased to 3.0 or $6.0 \mathrm{~g} \mathrm{l}^{-1}$.

Chemostat culture. The bacterium was grown in a chemostat system as described before (Ohta et al., 1989). For anaerobic cultures, the system was kept under a stream (200-300 $\mathrm{ml} \mathrm{h}^{-1}$ ) of $\mathrm{N}_{2}$, which was freed of traces of oxygen by passage over a gas-purifying column (Gas Clean GC-RX; Nikka Seiko). In the chemostat system the redox potential was measured continuously using a platinum electrode with an $\mathrm{Ag} / \mathrm{AgCl}$ reference cell and used to control the stirring speed in the culture. The electrode signal was measured with a redox regulator (model F0-11; Tokyo Rikakikai) calibrated against a quinhydrone reference solution at $\mathrm{pH} 4 \cdot 0$. In this system, manipulation of the air flow in combination with feedback control on the stirring speed made it possible to maintain a constant redox potential $( \pm 5-10 \mathrm{mV})$ between approximately $-400 \mathrm{mV}$ (anaerobic) and $+300 \mathrm{mV}$ (aerobic; near air saturation), depending on the exact medium composition and the air supply (Ohta \& Gottschal, 1988; Ohta et al., 1996b). In this study the redox potential of microaerobic culture was maintained at $-200 \mathrm{mV}$. The temperature of the culture was maintained at $37^{\circ} \mathrm{C}$, and the $\mathrm{pH}$ was maintained at $7 \cdot 0$ with automatic addition of $2 \mathrm{M} \mathrm{NaOH}$ or $2 \mathrm{M} \mathrm{HCl}$. The $\mathrm{OD}_{660}$ of cultures was measured in a $1 \mathrm{~cm}$ light path cuvette to determine the cell densities. The averaged coefficient of the dry cell weight at $\mathrm{OD}_{660}$ was $0 \cdot 852 \pm 0.055 \mathrm{mg}$ dry wt ml ${ }^{-1}$ per $\mathrm{OD}_{660}$ unit (mean $\pm \mathrm{SD}$ of 12 runs at dilution rates between 0.04 and $0.25 \mathrm{~h}^{-1}$ ) (Ohta et al., 1989). The relationship is linear up to $0 \cdot 6$ units of $\mathrm{OD}_{660}$ (Ohta et al., 1989). The purity of the cultures was routinely checked on tryptic soy agar (BBL Microbiology Systems) plates.

Measurement of oxygen uptake by washed cells. Bacterial cells were sampled from chemostat cultures, washed twice with $100 \mathrm{mM}$ potassium MOPS buffer ( $\mathrm{pH} 7 \cdot 0$ ) containing $66 \mathrm{mM} \mathrm{NaCl}, 5 \mathrm{mM} \mathrm{KCl}, 2 \mathrm{mM} \mathrm{CaCl}$ and $0.5 \mathrm{mM} \mathrm{MgCl}_{2}$, and suspended at 34-50 $\mathrm{mg}^{2}$ dry w $\mathrm{ml}^{-1}$ in the MOPS buffer. Oxygen consumption by cell suspensions was measured at $37^{\circ} \mathrm{C}$ in a Hansatech oxygen electrode unit (type DW1). It consisted of a water-jacketed reaction chamber (volume, $1 \mathrm{ml}$ ), with a Clark-type oxygen electrode disc set in the floor. The chamber was closed with a stopper. In this unit, the magnetic follower that stirred the cell suspension spun directly above the membrane-covered electrode. The chamber contained the air-saturated MOPS buffer and an appropriate amount of the cell suspension was injected through a hole in the stopper. After the output signal had become constant, the reaction was started by the addition of fructose (final concentration $10 \mathrm{mM}$ ). The calibration of the electrode was made on the assumption that the dissolved oxygen concentration in air-saturated water was $217 \mu \mathrm{M}$ at $37^{\circ} \mathrm{C}$ (Kielley, 1963).

Chemical analysis. Formate, succinate and ethanol were determined by GLC, and fructose by the enzymic method described before (Ohta et al., 1989). Acetate was determined using an enzyme system consisting of acetyl-CoA synthetase, citrate synthase and malate dehydrogenase (Boehringer Mannheim).

Calculations. The specific rate of ATP production during fructose fermentation $\left(q_{\mathrm{ATP}(\mathrm{fermen})}\right)$ was calculated by the following equation (Ohta et al., 1989):

$q_{\mathrm{ATP}(\mathrm{fermen})}=2 q_{\text {fructose }}+q_{\text {acetate }}$

where $q_{\text {fructose }}$ and $q_{\text {acetate }}$ are the specific rates of fructose consumption and acetate formation, respectively, and $q$ is expressed in mmol substrate consumed or formed ( $\mathrm{g}$ dry $\mathrm{wt})^{-1} \mathrm{~h}^{-1}$. The ATP yield from fructose fermentation (mol ATP formed per mol fructose metabolized) was calculated as the ratio of $q_{\mathrm{ATP(fermen)}}$ to $q_{\text {fructose }}$. For the anaerobic cultures, the $Y_{\text {ATP }}$ (g cells produced per mol ATP consumed) was estimated by the ratio of the growth yield on fructose $\left(Y_{\text {fructose }}\right)$ to the ATP yield from fructose fermentation. Based on the discussion by Stouthamer \& Bettenhaussen (1975), we assumed that the $Y_{\text {ATP }}$ was dependent on the growth rate and did not change significantly with a change from anaerobic to microaerobic conditions when medium composition and culture $\mathrm{pH}$ were kept constant. Thus, for microaerobic cultures, the specific rates of total ATP production $\left(q_{\mathrm{ATP}(\text { total })}\right)$ and ATP production through respiratory chain phosphorylation $\left(q_{\mathrm{ATP}(\mathrm{respi})}\right)$ were estimated by the following equation:

$\begin{aligned} q_{\mathrm{ATP}(\mathrm{total})} & =q_{\mathrm{ATP}(\mathrm{fermen})}+q_{\mathrm{ATP}(\mathrm{respi})} \\ & =\left(Y_{\text {fructose }} / \mathrm{Y}_{\mathrm{ATP}}\right) q_{\text {fructose }}\end{aligned}$ 


\section{RESULTS AND DISCUSSION}

\section{Anaerobic growth}

A. actinomycetemcomitans 301-b was grown anaerobically in a fructose-limited chemostat culture and steady states were obtained at dilution rates $(D)$ ranging from 0.04 to $0.20 \mathrm{~h}^{-1}$. In the steady-state cultures, the redox potential values were recorded at -470 to $-400 \mathrm{mV}$ and residual fructose concentrations were less than $0.05 \mathrm{mM}$. The molar growth yield on fructose $\left(Y_{\text {fructose }}\right)$ was $36.9 \mathrm{~g}$ dry wt (mol fructose $)^{-1}$ at $D=0.04 \mathrm{~h}^{-1}$ and increased to $47.7 \mathrm{~g}$ dry wt $(\mathrm{mol} \text { fructose })^{-1}$ at $D=$ $0 \cdot 20 \mathrm{~h}^{-1}$ (Fig. 1a). The plot of the specific rate of fructose consumption ( $\left.q_{\text {fructose }}\right)$ against the corresponding $D$ value yielded a straight line (Fig. 1b), indicating that the $q_{\text {fructose }}$ is a linear function of dilution rate. The relationship approximated to:

$q_{\text {fructose }}=19 \cdot 9 D+0.359(r=0.999)$

Assuming the following relationship (Tempest \& Neijssel, 1984)

$q=D / Y^{\max }+m$

the maximum growth yield $\left(Y^{\max }\right)$ and the maintenance coefficient $(m)$ were estimated: $Y_{\text {fructose }}^{\max } 50 \cdot 3 \mathrm{~g}$ dry wt
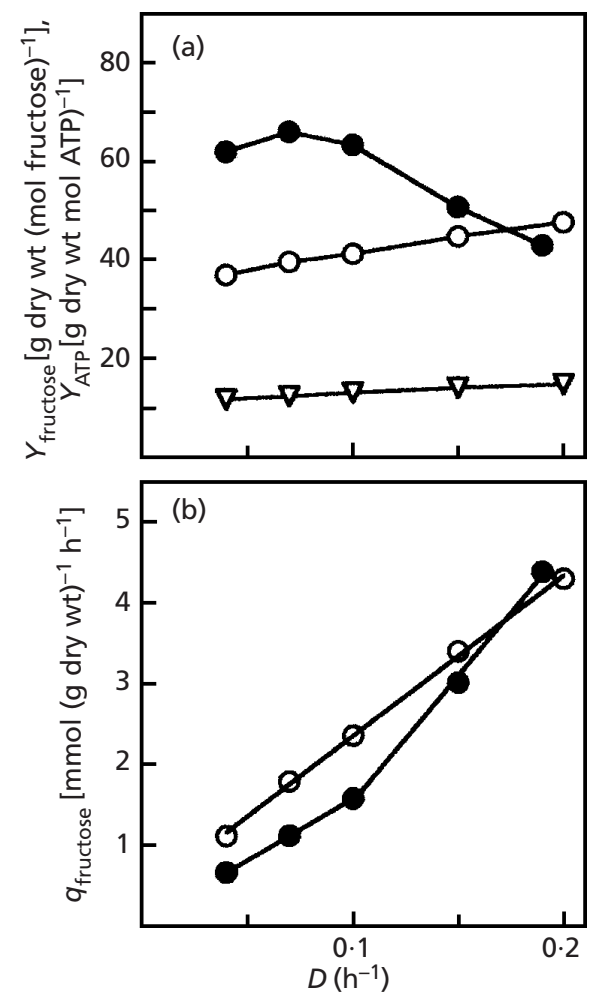

Fig. 1. Molar growth yield on fructose (a) and specific rate of fructose consumption (b) as functions of the dilution rate in anaerobic $(O)$ and microaerobic $(O)$ fructose-limited chemostat cultures of $A$. actinomycetemcomitans 301-b. $\nabla, Y_{\text {ATP }}$ calculated for the anaerobic cultures. The growth medium (control medium) contained $5.2 \mathrm{mM} \mathrm{K}^{+}$and $24 \mathrm{mM} \mathrm{Na}^{+}$.



Fig. 2. Specific production rates of formate $(O)$, acetate (0), ethanol $(\nabla)$ and succinate $(\nabla)$ as functions of the dilution rate in anaerobic (a) and microaerobic (b) fructose-limited chemostat cultures of $A$. actinomycetemcomitans 301-b. The growth medium (control medium) contained $5.2 \mathrm{mM} \mathrm{K}^{+}$and $24 \mathrm{mM} \mathrm{Na}^{+}$.

$(\mathrm{mol} \text { fructose })^{-1}$ and $m_{\text {fructose }} 0.359 \mathrm{mmol}(\mathrm{g} \text { dry wt })^{-1}$ $\mathrm{h}^{-1}$, respectively.

The main fermentation products from anaerobic fructose-limited chemostat cultures of A. actinomycetemcomitans were acetate, formate, ethanol and succinate. Lactate was not detected at any of the dilution rates tested. Carbon recoveries, which were estimated from the ratios of amounts of fermentation-productcarbons to amounts of fructose-carbon consumed, were between 88 and $91 \%$. The specific formation rates of fermentation products as functions of the dilution rate are shown in Fig. 2(a). Acetate was the most abundant product and its formation was proportional to dilution rate. Succinate was the second most abundant product at dilution rates below $0 \cdot 10 \mathrm{~h}^{-1}$, but its formation did not increase with increasing dilution rate. Increases in the formation of formate and ethanol showed biphasic patterns and the slopes were higher at dilution rates above $0 \cdot 10 \mathrm{~h}^{-1}$.

\section{Microaerobic growth and oxygen consumption activity}

When A. actinomycetemcomitans 301-b was grown in microaerobic fructose-limited chemostat cultures maintained at an $E_{\mathrm{h}}$ value of $-200 \mathrm{mV}$, steady states were 
obtained at dilution rates ranging from $0 \cdot 04$ to $0 \cdot 19 \mathrm{~h}^{-1}$. As shown in Fig. 1(a), the recorded $Y_{\text {fructose }}$ values below $D=0 \cdot 10 \mathrm{~h}^{-1}$ were higher than those of the corresponding anaerobic cultures. However, above $D=0 \cdot 10 \mathrm{~h}^{-1}$, the $Y_{\text {fructose }}$ value decreased. Increasing the dilution rate further to $0 \cdot 20 \mathrm{~h}^{-1}$ led to a further decrease in the cell density of culture followed by washout. The relationship between $q_{\text {fructose }}$ and dilution rate showed a biphasic pattern (Fig. 1b) and the $Y_{\text {fructose }}^{\max }$ values were estimated to be $65.4 \mathrm{~g}$ dry wt (mol fructose) ${ }^{-1}$ (first phase) and $32 \cdot 2 \mathrm{~g}$ dry wt (mol fructose) ${ }^{-1}$ (second phase). The firstphase value is 1.3 times higher than the $Y_{\text {fructose }}^{\max }$ of the anaerobic culture but the second-phase value is $64 \%$ of the anaerobic value. In the microaerobic culture, acetate was the sole fermentation product at dilution rates lower than $0 \cdot 10 \mathrm{~h}^{-1}$ and its formation was not proportional to dilution rate (Fig. 2b). With increasing dilution rate to $0 \cdot 15$ then $0 \cdot 19 \mathrm{~h}^{-1}$, a proportional increase in acetate formation started simultaneously with the production of formate and ethanol. The estimated carbon recovery was the lowest $(40 \%)$ at $D=$ $0 \cdot 10 \mathrm{~h}^{-1}$ and ranged from 52 to $71 \%$ at the other dilution rates.

To examine whether or not an induction of respiratory capacity with fructose occurs upon microaerobic culturing, washed cells were prepared from the anaerobic $\left(E_{\mathrm{h}}=-410 \mathrm{mV}\right)$ and microaerobic $\left(E_{\mathrm{h}}=-270\right.$ and $-200 \mathrm{mV}$ ) fructose-limited chemostat cultures run at $D$ $=0 \cdot 10 \mathrm{~h}^{-1}$ then oxygen uptake rates by the two sets of washed cells were compared. Fructose-dependent oxygen uptake activity of the microaerobically grown cells was slightly lower $\left[1.26-1.36 \mathrm{mmol} \mathrm{O}_{2} \mathrm{~h}^{-1}\right.$ (g dry $\mathrm{wt})^{-1}$ (mean of duplicate determinations) $]^{2}$ than that of anaerobically grown cells $\left[1.54 \mathrm{mmol} \mathrm{O}_{2} \mathrm{~h}^{-1}\right.$ (g dry $\mathrm{wt})^{-1}$, indicating that no induction but a small suppression of respiratory capacity occurred in the microaerobic culture. It was also noted that the measured oxygen uptake rates were significantly low compared with those of washed cells of batch-grown Escherichia coli K-12 [about $8 \mathrm{mmol} \mathrm{O}_{2} \mathrm{~h}^{-1}$ (g dry wt) $)^{-1}$ ] (Ohta \& Taniguchi, 1988).

\section{Effect of $\mathrm{K}^{+}$on growth}

Our growth medium (AA medium) contained $5 \cdot 2 \mathrm{mM}$ $\mathrm{K}^{+}$, which was higher than the amount $(1 \mathrm{mM})$ just sufficient to meet the cellular requirement of a rapidly growing culture of the facultatively anaerobic, sugarfermenting Klebsiella aerogenes (K. pneumoniae) (Tempest \& Neijssel, 1984). However, considering that oral environments such as dental plaque and gingival fluid contain relatively high amounts of $\mathrm{K}^{+}(61.5$ $\pm 13.5 \mathrm{mM}$ for plaque fluid and $17.4 \pm 9.0 \mathrm{mM}$ for gingival fluid) (Tatevossian \& Gould, 1976), higher extracellular $\mathrm{K}^{+}$concentrations might be required for rapid growth of A. actinomycetemcomitans. Therefore, fructose-limited growth of strain 301-b was examined using media containing high $\mathrm{K}^{+}$concentrations. In these media, the $\mathrm{Na}^{+}$concentration was fixed at $24 \mathrm{mM}$. The $Y_{\text {fructose }}$ of the steady-state microaerobic cultures $\left(E_{\mathrm{h}}=\right.$ $-200 \mathrm{mV}$ ) with 81 and $162 \mathrm{mM} \mathrm{K}^{+}$were 1.3 times
Table 1. Effects of $\mathrm{K}^{+}$and $\mathrm{Na}^{+}$on the molar growth yield on fructose in anaerobic $\left(E_{\mathrm{h}}<-400 \mathrm{mV}\right)$ and microaerobic $\left(E_{\mathrm{h}}=-200 \mathrm{mV}\right)$ fructose-limited chemostat cultures $\left(D=0 \cdot 15 \mathrm{~h}^{-1}\right)$ of $A$. actinomycetemcomitans 301-b

\begin{tabular}{|c|c|c|c|}
\hline \multicolumn{2}{|c|}{ Ion concn $(\mathrm{mM})$} & \multicolumn{2}{|c|}{$Y_{\text {fructose }}\left[\mathrm{g} \text { dry wt }(\mathrm{mol} \text { fructose })^{-1}\right]^{*}$} \\
\hline $\mathbf{K}^{+}$ & $\mathrm{Na}^{+}$ & Anaerobic culture & Microaerobic culture \\
\hline $5 \cdot 2$ & 24 & $47 \cdot 2(2)[100]$ & $51 \cdot 7(2)[110]$ \\
\hline 21 & 24 & $47 \cdot 0$ (1) $[100]$ & $43 \cdot 9$ (1) $[93]$ \\
\hline 41 & 24 & $48 \cdot 2$ (1) [102] & $51 \cdot 1(1)[108]$ \\
\hline 81 & 24 & $41 \cdot 5(1)[88]$ & $65 \cdot 6 \pm 1 \cdot 5(3)[139]$ \\
\hline 162 & 24 & ND & $64 \cdot 8(2)[137]$ \\
\hline $5 \cdot 2$ & 55 & $52 \cdot 2(1)[111]$ & $58 \cdot 8(2)[125]$ \\
\hline $5 \cdot 2$ & 106 & $51 \cdot 5(2)[109]$ & $56 \cdot 2(1)[119]$ \\
\hline
\end{tabular}

*Values in parentheses represent the number of independent experiments. For duplicate and triplicate experiments, yield values are the mean and the mean $\pm S D$, respectively. Values in square brackets are percentage values expressed relative to that of the anaerobic culture with $5 \cdot 2 \mathrm{mM} \mathrm{K}^{+}$and $24 \mathrm{mM} \mathrm{Na}^{+}$. ND, Not determined.

higher than the values of the low $(5 \cdot 2 \mathrm{mM}) \mathrm{K}^{+}$culture (Table 1). In contrast, for the anaerobic cultures, increases in extracellular $\mathrm{K}^{+}$concentrations did not result in an increase in the $Y_{\text {fructose }}$. As a control, the effect of $\mathrm{Na}^{+}$on the anaerobic and microaerobic fructose-limited growth (at $D=0 \cdot 15 \mathrm{~h}^{-1}$ ) was also examined; the medium $\mathrm{K}^{+}$concentration was fixed at $5.2 \mathrm{mM}$. No significant changes in the $Y_{\text {fructose }}$ were found for anaerobic or microaerobic cultures with increasing $\mathrm{Na}^{+}$concentration from 24 to 55 then to $106 \mathrm{mM}$ (Table 1).

\section{Growth in high- $\mathrm{K}^{+}$and high-Na+ cultures}

The effect of growth rate on the fructose metabolism of A. actinomycetemcomitans $301-\mathrm{b}$ in a high $-\mathrm{K}^{+}$medium $\left(81.2 \mathrm{mM} \mathrm{K} \mathrm{K}^{+}\right.$and $\left.24 \mathrm{mM} \mathrm{Na} \mathrm{Na}^{+}\right)$was examined in fructose-limited chemostat cultures. Steady states of both anaerobic and microaerobic cultures were obtained at dilution rates ranging from 0.04 to $0 \cdot 20 \mathrm{~h}^{-1}$. With increasing dilution rate, the $Y_{\text {fructose }}$ of anaerobic cultures increased to a maximum $[48.5 \mathrm{~g}$ dry wt $(\mathrm{mol}$ fructose $)^{-1}$ ] at $D=0 \cdot 10 \mathrm{~h}^{-1}$ and decreased slightly above $D=0.10 \mathrm{~h}^{-1}$ (Fig. 3a). In the microaerobic cultures, the $Y_{\text {fructose }}$ values were 1.4-2.0 times higher than those of the corresponding anaerobic cultures over the range of dilution rates tested, although a successive small decrease in the yield was observed as the dilution rate increased (Fig. 3a). Growth of A. actinomycetemcomitans 301-b was also examined in high- $\mathrm{Na}^{+}$medium $\left(5 \cdot 2 \mathrm{mM} \mathrm{K}^{+}\right.$and $\left.106 \mathrm{mM} \mathrm{Na}^{+}\right)$. Steady states were obtained for both anaerobic and microaerobic fructoselimited chemostat cultures at dilution rates between $0 \cdot 04$ and $0.20 \mathrm{~h}^{-1}$. The maximum $Y_{\text {fructose }}$ value of the anaerobic cultures was recorded at $D=0 \cdot 15 \mathrm{~h}^{-1}[50 \cdot 0 \mathrm{~g}$ 


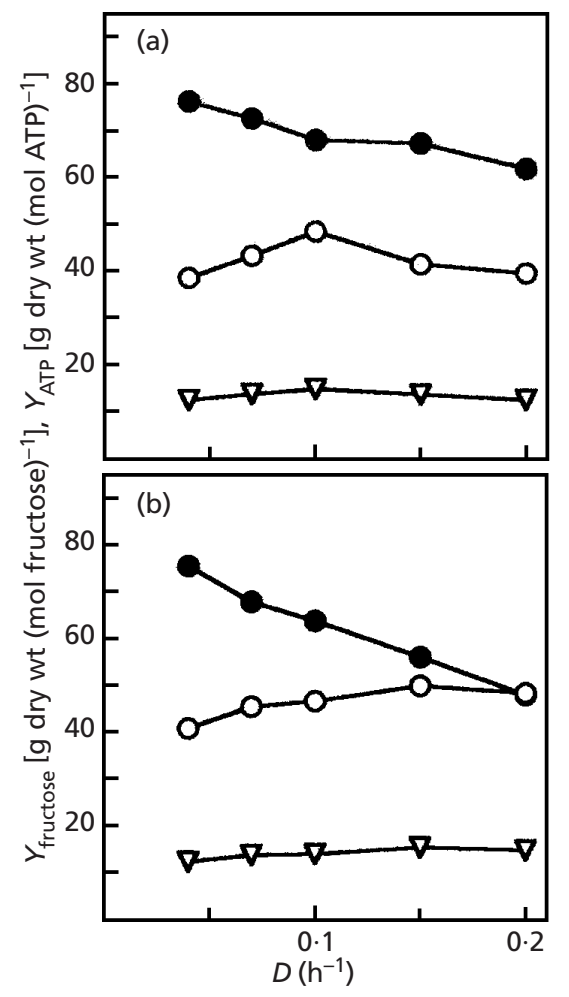

Fig. 3. Effect of increased extracellular concentration of $\mathrm{K}^{+}$ $\left(81 \mathrm{mM} \mathrm{K}^{+}\right.$and $24 \mathrm{mM} \mathrm{Na}^{+}$) (a) and $\mathrm{Na}^{+}\left(5.2 \mathrm{mM} \mathrm{K}^{+}\right.$and $106 \mathrm{mM} \mathrm{Na}^{+}$) (b) on the molar growth yield on fructose in anaerobic $(O)$ and microaerobic $(\bullet)$ fructose-limited chemostat cultures of $A$. actinomycetemcomitans 301-b. $\nabla, Y_{\text {ATP }}$ calculated for the anaerobic cultures.

dry wt (mol fructose) $)^{-1}$ and the $Y_{\text {fructose }}$ decreased slightly at $D=0 \cdot 20 \mathrm{~h}^{-1}$ (Fig. 3b). The $Y_{\text {fructose }}$ of the microaerobic culture at $D=0.04 \mathrm{~h}^{-1}$ was 1.9 times higher than that of the corresponding anaerobic cultures but the $Y_{\text {fructose }}$ decreased sharply to the level of the anaerobic cultures with increasing dilution rate (Fig. $3 b)$.

In the anaerobic high- $\mathrm{K}^{+}$and high- $\mathrm{Na}^{+}$cultures, acetate, formate, ethanol and succinate were major fermentation products. Similar to the product formation profile of the anaerobic control culture, the acetate formation rate was a linear function of dilution rate. The formation of formate and ethanol showed biphasic patterns and increased markedly at higher dilution rates (Fig. 4a, c). Succinate formation was also found but it was not significantly affected by dilution rate. The carbon recoveries for the anaerobic high- $\mathrm{K}^{+}$cultures were between 76 and $97 \%$ and those for the anaerobic high$\mathrm{Na}^{+}$cultures $88-100 \%$. In the microaerobic high- $\mathrm{K}^{+}$ culture, acetate formation was predominant over a wide range of dilution rates (Fig. 4b), while in the microaerobic high- $\mathrm{Na}^{+}$culture, formation of both acetate and formate was evident (Fig. 4d). The carbon recoveries for the microaerobic high- $\mathrm{K}^{+}$cultures were between 67 and $80 \%$ and those for the microaerobic high- $\mathrm{Na}^{+}$cultures $73-84 \%$.



Fig. 4. Effect of increased extracellular concentration of $\mathrm{K}^{+}$ $\left(81 \mathrm{mM} \mathrm{K}^{+}\right.$and $\left.24 \mathrm{mM} \mathrm{Na}^{+}\right)(\mathrm{a}, \mathrm{b})$ and $\mathrm{Na}^{+}\left(5.2 \mathrm{mM} \mathrm{K}^{+}\right.$and $106 \mathrm{mM} \mathrm{Na}^{+}$) (c, d) on the specific production rates of formate $(\bigcirc)$, acetate $(\boldsymbol{\bullet})$, ethanol $(\nabla)$ and succinate $(\boldsymbol{\nabla})$ in anaerobic $(\mathrm{a}$, $c)$ and microaerobic $(b, d)$ fructose-limited chemostat cultures of $A$. actinomycetemcomitans 301-b.

\section{Estimation of ATP production rate during anaerobic growth}

For all the steady states of anaerobic chemostat cultures, with the control, high- $\mathrm{K}^{+}$and high- $\mathrm{Na}^{+}$media, the specific rate of ATP production from fructose fermentation $\left(q_{\mathrm{ATP}(\mathrm{fermen})}\right)$ was calculated and the relationships between $q_{\text {fructose }}$ and $q_{\mathrm{ATP}(\text { fermen })}$ were examined. As shown in Fig. 5, irrespective of the $\mathrm{K}^{+}$and $\mathrm{Na}^{+}$ concentrations in the medium, plots of the $q_{\mathrm{ATP}(\mathrm{fermen})}$ values against the corresponding $q_{\text {fructose }}$ values yielded a single straight line with the following approximated equation:

$$
q_{\mathrm{ATP}(\mathrm{fermen})}=3.13 q_{\text {fructose }}+0 \cdot 103(r=0.998)
$$

This indicates that under the anaerobic condition, the specific rate of fermentation-derived ATP production was not affected by the increases in extracellular $\mathrm{K}^{+}$and $\mathrm{Na}^{+}$concentrations, and the ATP yield was constant with the value of $3.13 \mathrm{~mol}$ ATP per mol fructose.

\section{Estimation of ATP production during microaerobic growth}

In the microaerobic control cultures, the specific rate of ATP production from fermentation $\left(q_{\mathrm{ATP}(\mathrm{fermen})}\right)$ was also a linear function of the fructose consumption rate 




Fig. 5. Specific rate of ATP production from fermentation as a function of the specific rate of fructose consumption in anaerobic fructose-limited cultures of $A$. actinomycetemcomitans 301-b: control $\left(5 \cdot 2 \mathrm{mM} \mathrm{K}^{+}\right.$and $24 \mathrm{mM} \mathrm{Na}^{+}$) (O), high- $\mathrm{K}^{+}\left(81 \mathrm{mM} \mathrm{K} \mathrm{K}^{+}\right.$and $\left.24 \mathrm{mM} \mathrm{Na}\right)(\nabla)$ and high- $\mathrm{Na}^{+}$ $\left(5.2 \mathrm{mM} \mathrm{K}^{+}\right.$and $\left.106 \mathrm{mM} \mathrm{Na}^{+}\right)(\square)$. The specific rate of ATP production from fermentation $\left(q_{\text {ATP(fermen) }}\right)$ was calculated by the equation $q_{\text {ATP(fermen) }}=2 q_{\text {fructose }}+q_{\text {acetate }}$. The linear relationship approximates to the equation $q_{\text {ATP(fermen) }}=3.13$ $q_{\text {fructose }}+0.103(r=0.998)$.

$\left(q_{\text {fructose }}\right)$ (Fig. 6a). However, the estimated ATP yield value $\left[2.49 \mathrm{~mol}\right.$ ATP $\left.(\mathrm{mol} \text { fructose })^{-1}\right]$ was lower than the anaerobic value $\left[3 \cdot 13 \mathrm{~mol}\right.$ ATP $\left.(\text { mol fructose })^{-1}\right]$. Assuming that the $Y_{\text {AтP }}$ was similar between anaerobic and microaerobic cultures, this result did not account for the increased $Y_{\text {fructose }}$ values in the microaerobic cultures at lower dilution rates. Hence, it was very likely that that the additional ATP was derived from respiration. The $Y_{\text {ATP }}$ calculated from the anaerobic cultures increased linearly from $11.7 \mathrm{~g}$ dry wt (mol
ATP $)^{-1}$ at $D=0.04 \mathrm{~h}^{-1}$ to $14.9 \mathrm{~g}$ dry wt $(\mathrm{mol} \mathrm{ATP})^{-1}$ at $D=0 \cdot 20 \mathrm{~h}^{-1}$ (Fig. 1a). Based on the assumption that the $Y_{\text {ATP }}$ was dependent of the growth rate and did not change significantly with a change from anaerobic to microaerobic conditions at a fixed growth rate, the specific rates of total ATP production $\left(q_{\mathrm{ATP}(\text { total })}\right)$ and ATP production via respiration $\left(q_{\mathrm{ATP}(\mathrm{respi})}\right)$ were estimated for each steady state culture. As shown in Fig. 6(a), the $q_{\mathrm{ATP}(\mathrm{respi})}$ was expected to parallel the $q_{\mathrm{ATP}(\mathrm{fermen})}$ until it reached a maximum value at a $q_{\text {fructose }}$ of $1.58 \mathrm{mmol}(\mathrm{g} \text { dry wt})^{-1} \mathrm{~h}^{-1}$, and to decrease above this $q_{\text {fructose }}$ value. From the ratio of $q_{\text {ATP(respi) }}$ to $q_{\text {fructose }}$, the respiration-derived ATP yield was estimated to be between 1.2 and $2.0 \mathrm{~mol}$ ATP (mol fructose) ${ }^{-1}$ below $q_{\text {fructose }}=1.58 \mathrm{mmol}(\mathrm{g} \text { dry wt })^{-1} \mathrm{~h}^{-1}$.

In the microaerobic high- $\mathrm{K}^{+}$and high- $\mathrm{Na}^{+}$cultures, the relationships between $q_{\text {fructose }}$ and $q_{\mathrm{ATP}(\mathrm{fermen})}$ were also linear and the estimated values of the ATP yield from fermentation were higher than the value of the control culture: $3 \cdot 14$ and 3.34 mol ATP (mol fructose) ${ }^{-1}$ for the high- $\mathrm{K}^{+}$and high- $\mathrm{Na}^{+}$cultures, respectively. This suggests that fermentation during microaerobic growth was affected by the extracellular $\mathrm{K}^{+}$and $\mathrm{Na}^{+}$ concentrations. However, the increased ATP yield from fermentation was comparable to the anaerobic value, and again this did not explain the higher $Y_{\text {fructose }}$ values in the microaerobic high- $\mathrm{K}^{+}$and high- $\mathrm{Na}^{+}$cultures. At a $q_{\text {fructose }}$ lower than $1.5 \mathrm{mmol}(\mathrm{g} \text { dry } \mathrm{wt})^{-1} \mathrm{~h}^{-1}$, the estimated $q_{\mathrm{ATP}(\mathrm{respi})}$ did not increase so evidently as in the control culture. However, above $q_{\text {fructose }}=$ $1.5 \mathrm{mmol}(\mathrm{g} \text { dry wt) })^{-1} \mathrm{~h}^{-1}$, the $q_{\mathrm{ATP}(\mathrm{respi})}$ of the high-K $\mathrm{K}^{+}$ culture increased markedly while that of the high- $\mathrm{Na}^{+}$ culture decreased (Fig. 6b, c). Therefore, it can be concluded that respiration during microaerobic growth is strongly influenced by extracellular $\mathrm{K}^{+}$and $\mathrm{Na}^{+}$, and

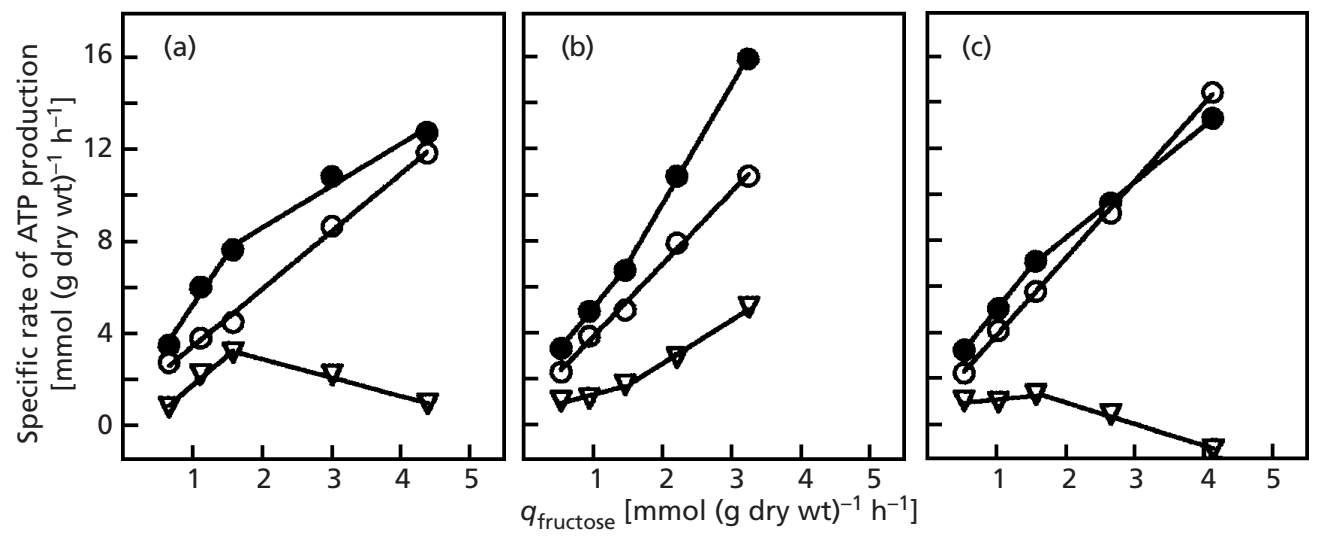

Fig. 6. Relationships between the specific rate of fructose consumption and the specific rates of total ATP production (0), ATP production from fermentation $(O)$ and ATP production from respiration $(\nabla)$ in microaerobic fructose-limited cultures of $A$. actinomycetemcomitans $301-\mathrm{b}$ : control $\left(5.2 \mathrm{mM} \mathrm{K}^{+}\right.$and $\left.24 \mathrm{mM} \mathrm{Na}^{+}\right)(\mathrm{a})$, high-K $\mathrm{K}^{+}\left(81 \mathrm{mM} \mathrm{K}^{+}\right.$and $24 \mathrm{mM}$ $\mathrm{Na}^{+}$) (b) and high- $\mathrm{Na}^{+}\left(5.2 \mathrm{mM} \mathrm{K}{ }^{+}\right.$and $106 \mathrm{mM} \mathrm{Na}$ ) $(c)$. The specific rates of total ATP production $\left(q_{\text {ATP(total })}\right)$ and ATP production via respiration $\left(q_{\text {ATP(respi) }}\right)$ were estimated by the equation $q_{\text {ATP(total) }}=q_{\text {ATP(fermen) }}+q_{\text {ATP(respi) }}=\left(Y_{\text {fructose }} / Y_{\text {ATP }}\right)$ $q_{\text {fructose }}$. In the control culture, the $Y_{\text {ATP }}$ value at $D=0.19 \mathrm{~h}^{-1}$ was obtained from the approximated linear relationship between $D$ and $Y_{\text {ATP }}: Y_{\text {ATP }}=20.3 D+10.9(r=0.996)$. The linear relationships approximate to the following equations: for the control culture (a), $q_{\text {ATP(fermen) }}=2.49 q_{\text {fructose }}+0.934(r=0.998)$; for the high-K ${ }^{+}$culture $(b), q_{\text {ATP(fermen })}=3.14$ $q_{\text {fructose }}+0.666(r=0.998) ;$ and for the high-Na+ culture $(c), q_{\text {ATP(fermen })}=3.34 q_{\text {fructose }}+0.524(r=1.000)$. 
higher concentrations of extracellular $\mathrm{K}^{+}$are required for respiration to occur in rapidly growing cells. In the microaerobic high- $\mathrm{K}^{+}$culture, the ATP yield from respiration was estimated to be between 1.18 and $1.91 \mathrm{~mol}$ ATP (mol fructose) $)^{-1}$ and the yield from fermentation between 3.32 and $4.24 \mathrm{~mol}$ ATP (mol fructose $)^{-1}$.

Satisfactory explanations are not yet available for the requirement of $\mathrm{K}^{+}$in cells growing rapidly under microaerobic conditions. One possibility is that mechanisms leading to a significant energy loss occur when cells are grown at higher rates in low $-\mathrm{K}^{+}$conditions. The most probable mechanism is a $\mathrm{K}^{+}$efflux system because a $\mathrm{K}^{+}$efflux system (kefC) was reported in not only E. coli (Bakker et al., 1987) but also Haemophilus influenzae: the latter is phylogenetically related to A. actinomycetemcomitans (Fleischmann et al., 1995). If this is the case for $A$. actinomycetemcomitans, it will be of interest to examine whether the leakage of $\mathrm{K}^{+}$from the cytoplasm is enhanced by exposure of cells to oxygen. The occurrence of a significant energy loss is also very likely for the high- $\mathrm{Na}^{+}$culture at higher growth rates because a negative effect of increasing $\mathrm{Na}^{+}$on the $Y_{\text {fructose }}$ was observed (Fig. 3b). Based on the database of the on-going genome analysis of A. actinomycetemcomitans strain HK1651 (B. A. Roe, F. Z. Najar, S. Clifton, T. Ducey, L. Lewis and D. W. Dyer, University of Oklahoma, Department of Chemistry and Biochemistry, and the University of Oklahoma Health Science Centre, Department of Microbiology and Immunology; http://www.genome.ou.edu/act.html), $\mathrm{Na}^{+} / \mathrm{H}^{+}$antiporter proteins are expected to be present in this organism, and thus in high- $\mathrm{Na}^{+}$conditions, extra energy will be needed to drive the $\mathrm{Na}^{+} / \mathrm{H}^{+}$antiporters for keeping intracellular $\mathrm{Na}^{+}$concentration low.

$\mathrm{K}^{+}$is the major cytoplasmic cation of growing bacterial cells (Silver, 1978). In Gram-negative bacteria such as E. coli and $K$. aerogenes (K. pneumoniae), intracellular $\mathrm{K}^{+}$ concentrations are as high as $0 \cdot 1-0.5 \mathrm{M}$ (Tempest et al., 1966; Kakinuma, 1998). In E. coli, $\mathrm{K}^{+}$can be taken up via a number of systems that differ in their affinity for $\mathrm{K}^{+}$; there is a constitutive low-affinity system (Trk) and an inducible high-affinity system (Kdp) (Bakker, 1993; Epstein et al., 1993). In H. influenzae, the gene encoding the Trk $\mathrm{K}^{+}$uptake protein is present but the gene of the Kdp system is absent (Fleischmann et al., 1995). This seems also to be true for A. actinomycetemcomitans, based on the database of its on-going genome analysis. The absence of the high-affinity system for $\mathrm{K}^{+}$uptake might be disadvantageous for A. actinomycetemcomitans in low- $\mathrm{K}^{+}$environments. This would be consistent with the fact that the primary ecological niche of $A$. actinomycetemcomitans is a $\mathrm{K}^{+}$-rich environment such as dental plaque $(61.5 \pm 13.5 \mathrm{mM})$ and gingival fluid $(17 \cdot 4 \pm 9 \cdot 0 \mathrm{mM})$ (Tatevossian \& Gould, 1976). Interestingly, it was reported that in patients suffering a more severe periodontitis, the gingival fluid $\mathrm{Na}^{+}$concentrations tended to be lower, and those for $\mathrm{K}^{+}$to be significantly higher (Bang et al., 1973). As discussed by Bang et al. (1973), in more severe cases of periodontitis the higher number of degenerating epithelial, connective tissue and blood cells contributes to increasing the $\mathrm{K}^{+}$ concentration of the exudates by the liberation of their intracellular content. Hence, it may be speculated that both moderate levels of oxygen tension and increased $\mathrm{K}^{+}$contents prevail in periodontal lesion sites and these constitute conditions favourable for the growth of $A$. actinomycetemcomitans.

\section{REFERENCES}

Bakker, E. P. (1993). Alkali Cation Transport Systems in Prokaryotes. Boca Raton, FL: CRC Press, Inc.

Bakker, E. P., Booth, I. R., Dinnbier, U., Epstein, W. \& Gajewska, A. (1987). Evidence for multiple $\mathrm{K}^{+}$export systems in Escherichia coli. J Bacteriol 169, 3743-3749.

Bang, J., Cimasoni, G., Rosenbusch, C. \& Duckert, A. (1973). Sodium, potassium and calcium contents of crevicular exudate: their relations to gingivitis and periodontitis. J Periodontol 44, 770-774.

Dzink, J. L., Tanner, A. C. R., Haffajee, A. D. \& Socransky, S. S. (1985). Gram negative species associated with active destructive periodontal lesions. J Clin Periodontol 12, 648-659.

Epstein, W., Burrman, E., McLaggan, D. \& Naprstek, J. (1993). Multiple mechanisms, roles and controls of $\mathrm{K}^{+}$transport in Escherichia coli. Biochem Soc Trans 21, 1006-1010.

Fleischmann, R. D., Adams, M. D., White, O. \& 37 other authors (1995). Whole-genome random sequencing and assembly of Haemophilus influenzae Rd. Science 269, 496-512.

Hueting, S., de Lange, T. \& Tempest, D. W. (1979). Energy requirement for maintenance of the transmembrane potassium gradient in Klebsiella aerogenes NCTC 418: a continuous culture study. Arch Microbiol 123, 183-188.

Inouye, T., Ohta, H., Kokeguchi, K., Fukui, K. \& Kato, K. (1990). Colonial variation and fimbriation of Actinobacillus actinomycetemcomitans. FEMS Microbiol Lett 69, 13-18.

Kakinuma, Y. (1998). Inorganic cation transport and energy transduction in Enterococcus hirae and other streptococci. Microbiol Mol Biol Rev 62, 1021-1045.

Kielley, W. W. (1963). Preparation and assay of phosphorylating submitochondrial particles: sonicated mitochondria. Methods Enzymol 6, 272-277.

Loesche, W. J., Gusberti, F., Mettraux, G., Higgins, T. \& Syed, S. (1983). Relationship between oxygen tension and subgingival bacterial flora in untreated human periodontal pockets. Infect Immun 42, 659-667.

Mannheim, W., Stieler, W., Wolf, G. \& Zabel, R. (1978). Taxonomic significance of respiratory quinones and fumarate respiration in Actinobacillus and Pasteurella. Int J Syst Bacteriol 28, 7-13.

Ohta, H. \& Gottschal, J. C. (1988). Microaerophilic growth of Wolinella recta ATCC 33238. FEMS Microbiol Ecol 53, 79-86.

Ohta, H. \& Taniguchi, S. (1988). Respiratory characteristics of two oligotrophic bacteria: Agromonas oligotrophica JCM 1494 and Aeromonas hydrophila 315. J Gen Appl Microbiol 34, 355-365.

Ohta, H., Kokeguchi, S., Fukui, K. \& Kato, K. (1987). Leukotoxic activity in Actinobacillus (Haemophilus) actinomycetemcomitans isolated from periodontal disease patients. Microbiol Immunol 31, 313-325. 
Ohta, H., Fukui, K. \& Kato, K. (1989). Effect of bicarbonate on the growth of Actinobacillus actinomycetemcomitans in anaerobic fructose-limited chemostat cultures. J Gen Microbiol 135, 3485-3495.

Ohta, H., Miyagi, A., Kato, K. \& Fukui, K. (1996a). The relationships between leukotoxin production, growth rate and the bicarbonate concentration in a toxin-production-variable strain of Actinobacillus actinomycetemcomitans. Microbiology 142, 963-970.

Ohta, H., Moriki, D., Miyagi, A., Watanabe, T., Kato, K. \& Fukui, K. (1996b). Microaerophilic property of Actinobacillus actinomycetemcomitans in fructose-limited chemostat cultures. FEMS Microbiol Lett 136, 191-196.

Silver, S. (1978). Transport of cations and anions. In Bacterial Transport, pp. 221-234. Edited by B. P. Rosen. New York: Marcel Dekker.

Slots, J. \& Schonfeld, S. E. (1991). Actinobacillus actinomycetemcomitans in localized juvenile periodontitis. In Periodontal Disease: Pathogens and Host Immune Responses, pp. 53-64. Edited by S. Hamada, S. C. Holt \& J. R. McGhee. Tokyo: Quintessence Publishing.

Slots, J., Reynolds, H. S. \& Genco, R. J. (1980). Actinobacillus actinomycetemcomitans in human periodontal disease: a cross- sectional microbiological investigation. Infect Immun 29, 1013-1020.

Stouthamer, A. H. \& Bettenhaussen, C. W. (1975). Determination of the efficiency of oxidative phosphorylation in continuous cultures of Aerobacter aerogenes. Arch Microbiol 102, 187-192.

Tatevossian, A. \& Gould, C. T. (1976). The composition of the aqueous phase in human dental plaque. Arch Oral Biol 21, 319-323.

Tempest, D. W. \& Neijssel, O. M. (1984). The status of $Y_{\text {ATP }}$ and maintenance energy as biologically interpretable phenomena. Annu Rev Microbiol 38, 459-486.

Tempest, D. W., Dicks, J. W. \& Hunter, J. R. (1966). The interrelationship between potassium, magnesium and phosphorus in potassium-limited chemostat cultures of Aerobacter aerogenes. $J$ Gen Microbiol 45, 135-146.

Wilson, M. \& Henderson, B. (1995). Virulence factors of Actinobacillus actinomycetemcomitans relevant to the pathogenesis of inflammatory periodontal disease. FEMS Microbiol Rev 17, 365-379.

Zambon, J. (1985). Actinobacillus actinomycetemcomitans in human periodontal disease. J Clin Periodontol 12, 1-20.

Received 23 January 2001; revised 22 May 2001; accepted 5 June 2001. 